\title{
Sustainable social distancing through facemask use and testing during the Covid-19 pandemic
}

Diego Chowell ${ }^{1}$, Kimberlyn Roosa ${ }^{2}$, Ranu Dhillon ${ }^{3}$, Gerardo Chowell ${ }^{\star}$, Devabhaktuni Srikrishna ${ }^{*}$

${ }^{1}$ Memorial Sloan Kettering Cancer Center, New York, New York

2 Department of Population Health Sciences, Georgia State University School of Public Health, Atlanta, Georgia

${ }^{3}$ Division of Global Health Equity, Brigham and Women's Hospital Boston, MA 02115

${ }^{4}$ Patient Knowhow, Inc.

*Correspondence to: Gerardo Chowell (gchowell@gsu.edu) or Devabhaktuni Srikrishna (sri.devabhaktuni@gmail.com) 
medRxiv preprint doi: https://doi.org/10.1101/2020.04.01.20049981; this version posted May 6, 2020. The copyright holder for this preprint (which was not certified by peer review) is the author/funder, who has granted medRxiv a license to display the preprint in perpetuity. All rights reserved. No reuse allowed without permission.

Recent reports have documented substantial proportions of asymptomatic or mildly symptomatic Covid-19 infections that may also be infectious [1-3] as well as the potential role of respiratory droplets and contaminated surfaces in driving SARS-CoV-2 transmission [4]. While facemask use is promoted in healthcare settings as part of infection control protocols [5-8], its use during the COVID-19 pandemic varies across countries $[9,10]$. As the COVID-19 pandemic rages on, widespread facemask use has been recently recommended by Dr. George Gao, the director-general of the Chinese Center for Disease Control and Prevention (CDC) [11].

Any plan for stopping the ongoing 2019-nCov pandemic must be based on a quantitative understanding of the proportion of the population that needs to be protected by effective control measures such that each infected person infects no more than one other person on average (the effective reproductive number, $R<1$ ), at which point transmission contracts and eventually burns out. Based on a modeling analysis, we show that the pandemic may be readily controllable through a combination of testing, treatment if necessary, and self-isolation after testing positive (TTI) of symptomatic individuals together with social protection (e.g., facemask use, handwashing).

We used an SEIR-type model incorporating asymptomatic but infectious individuals $(40 \%)$ [1-3] to investigate how individual protective behaviors, different levels of testing, and isolation influence the transmission and control of the COVID-19 pandemic (Appendix). When the basic reproduction number, $R_{0}$, is 2.4 [12], 65\% effective social protection alone (35\% of the unprotected transmission) brings the R below 1 (Appendix). Alternatively, $20 \%$ effective social protection brings the reproduction number below 1.0 so long as $75 \%$ of the symptomatic population is covered by TTI within 12 hours of symptom onset (Fig. 1A and Appendix). Even with 20\% effective social protection, TTI of 1 in 4 symptomatic individuals can substantially "flatten the curve", cutting the peak daily incidence in half (Fig. 1B and Appendix).

Therefore, our results suggest that the COVID-19 pandemic can be controlled through an imperfect though sufficient combination of testing, contact tracing, and protective measures like masks and distancing when in public. 
medRxiv preprint doi: https://doi.org/10.1101/2020.04.01.20049981; this version posted May 6, 2020. The copyright holder for this preprint (which was not certified by peer review) is the author/funder, who has granted medRxiv a license to display the preprint in perpetuity.

All rights reserved. No reuse allowed without permission.

\section{A}

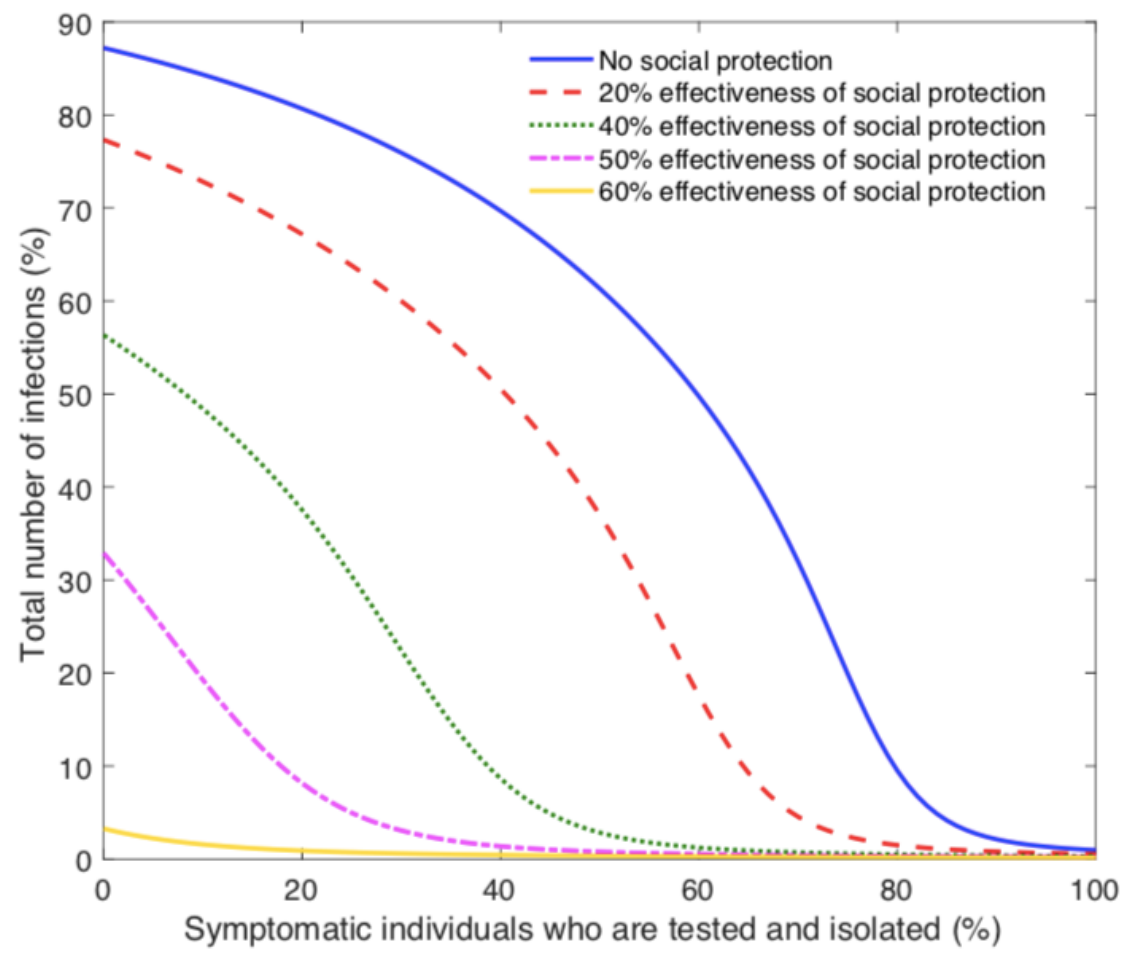

B

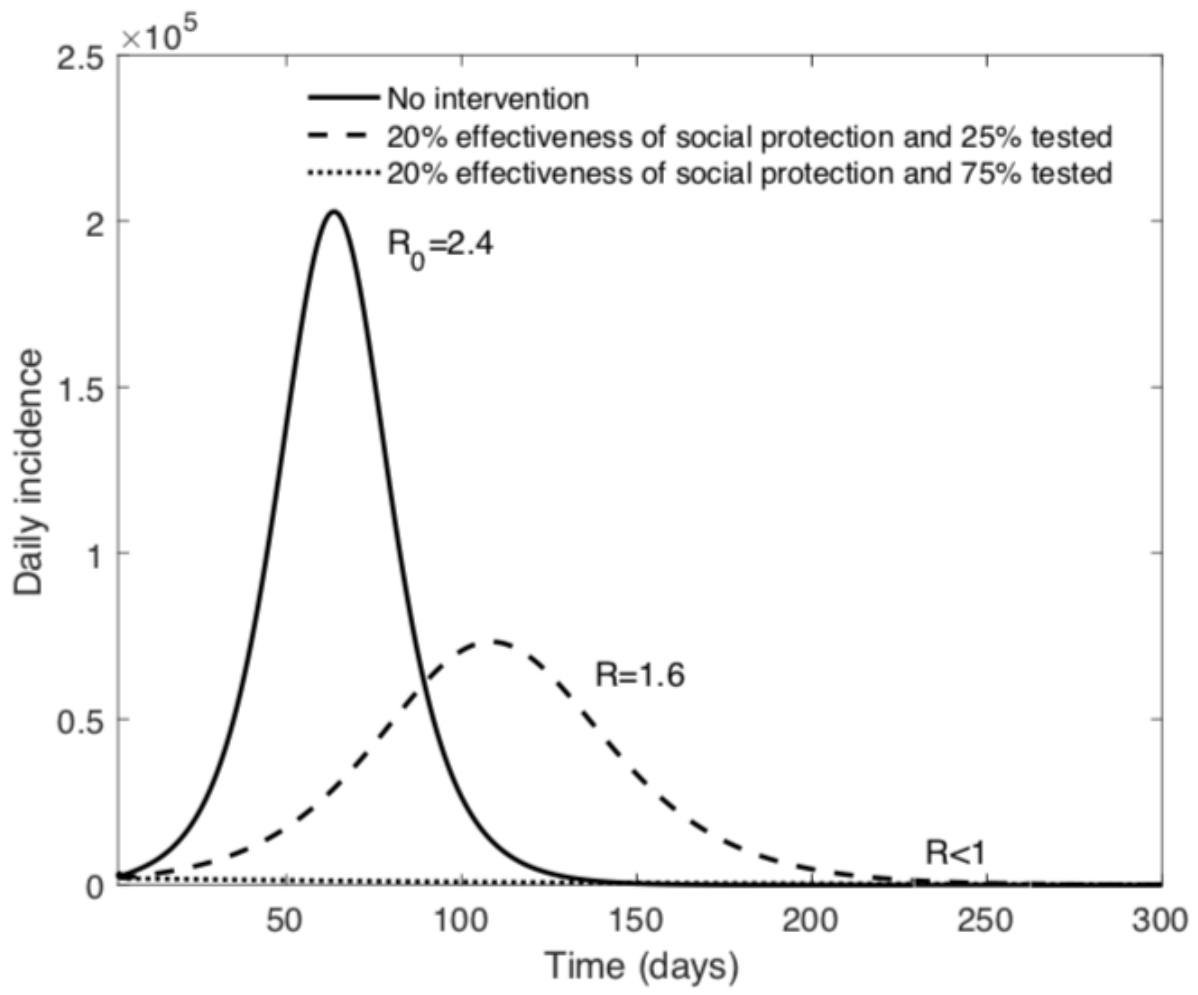


medRxiv preprint doi: https://doi.org/10.1101/2020.04.01.20049981; this version posted May 6, 2020. The copyright holder for this preprint (which was not certified by peer review) is the author/funder, who has granted medRxiv a license to display the preprint in perpetuity. All rights reserved. No reuse allowed without permission.

Figure 1. (A) Total number of infections in a population of 10 million individuals for varying levels of social protection and testing (TTI) at 12 hours testing delay and assuming $40 \%$ asymptomatic transmission. (B) Daily incidence in a population of 10 million individuals for $20 \%$ effectiveness of social protection and varying levels of testing (TTI) at 12 hours testing delay and assuming $40 \%$ asymptomatic transmission. Initial conditions were set as follows, susceptible individuals: 9,943,400; symptomatic individuals who underwent testing: 40,000; asymptomatic individuals: 16,000; and deceased individuals: 600 . 
medRxiv preprint doi: https://doi.org/10.1101/2020.04.01.20049981; this version posted May 6, 2020. The copyright holder for this preprint

(which was not certified by peer review) is the author/funder, who has granted medRxiv a license to display the preprint in perpetuity.

All rights reserved. No reuse allowed without permission.

\section{References}

1. Zou L. et al. SARS-CoV-2 Viral Load in Upper Respiratory Specimens of Infected Patients. N Engl. J. Med. 382, 1177-1179 2020.

2. Nishiura $\mathrm{H}$ et al. Estimation of the asymptomatic ratio of novel coronavirus infections (COVID-19). Int. J. Infect. Dis. 2020.

3. Mizumoto K, Kagaya K, Zarebski A, Chowell G. Estimating the asymptomatic proportion of coronavirus disease 2019 (COVID-19) cases on board the Diamond Princess cruise ship, Yokohama, Japan, 2020. Euro Surveill. 25, 20001802020.

4. Neeltje van Doremalen N., Morris H., Gamble A., Williamson B.N., Tamin A., Harcourt J.L., Thornburg N.J., Gerber S.I., Lloyd-Smith J.O., de Wit E., Munster V.J., (2020) Aerosol and Surface Stability of SARS-CoV-2 as Compared with SARS-CoV1, N. Engl. J. Med., DOI: 10.1056/NEJMc2004973.

5. Offeddu V, Yung CF, Low MSF, CC Tam. Effectiveness of masks and respirators against respiratory infections in healthcare workers: a systematic review and metaanalysis. Clinical Infectious Diseases 2017.

6. Wang X, Pan Z, Cheng Z. Association between 2019-nCoV transmission and N95 respirator use. Journal of Hospital Infection 2020.

7. Maclntyre CR, Chughtai AA, Rahman B. The efficacy of medical masks and respirators against respiratory infection in healthcare workers. influenza and other respiratory viruses 2017.

8. Radonovich LJ, Simberkoff MS, Bessesen MT. N95 respirators vs medical masks for preventing influenza among health care personnel: a randomized clinical trial. Jama 2019.

9. Feng S, Shen C, Xia N, Song W, Fan M, Cowling BJ. Rational use of face masks in the COVID-19 pandemic. The Lancet Respiratory Medicine 2020.

10. Normile D. Coronavirus cases have dropped sharply in South Korea. What's the secret to its success? Science 2020.

11. Cohen J. Not wearing masks to protect against coronavirus is a 'big mistake,' top Chinese scientist says. Science 2020.

12. Li Q et al. Early Transmission Dynamics in Wuhan, China, of Novel Coronavirus- 


\section{Appendix}

\section{Sustainable social distancing through facemask use and testing during the Covid-19 pandemic}

\section{Basic reproduction number, $\mathbf{R}_{0}$}

The basic reproduction number, $\mathrm{R}_{0}$, is defined as the average number of secondary cases generated by primary infectious individuals during the early transmission phase in a completely susceptible population and in the absence of control interventions. This is a key metric to gauge the intensity and type of interventions that need to be implemented in order to bring the epidemic under control. For the ongoing COVID-19 pandemic, $\mathrm{R}_{0}$ has been estimated at 2.4 [1].

\section{Reproduction number with testing, isolation, and social protection}

The reproductive number, $\mathrm{R}$, quantifies the potential for infectious disease transmission in the context of a partially susceptible population. When $\mathrm{R}>1$, infection may spread in the population, and the rate of spread is higher with increasingly high values of $\mathrm{R}$. If $\mathrm{R}<1$, infection cannot be sustained and is unable to generate an epidemic. As there are seven classes that can contribute to new infections, the reproduction number is the sum of the contributions of the infectious classes:

The contributions of the individual compartments are as follows

$$
\begin{gathered}
R=R^{E_{2}}+R^{A_{n}}+R^{A_{s}}+R^{J a}+R^{I_{n}}+R^{I_{s}}+R^{J} \\
R^{E_{2}}=\beta \frac{q_{e}}{\kappa_{2}} \\
R^{A_{n}}=\beta \frac{\rho_{a}\left(1-n_{s}\right) q_{a} q}{\gamma_{1}} \\
R^{A_{s}}=\beta \frac{\rho_{a} n_{s} q_{a}}{\alpha} \\
R^{J a}=\beta \frac{\rho_{a} n_{s} h_{a} q_{a}}{\gamma_{2}}
\end{gathered}
$$




$$
\begin{gathered}
R^{I_{n}}=\beta \frac{\left(1-\rho_{a}\right)\left(1-\rho_{s}\right) q}{\gamma_{1}} \\
R^{I_{s}}=\beta \frac{\left(1-\rho_{a}\right) \rho_{s} q}{\alpha} \\
R^{J}=\beta \frac{\left(1-\rho_{a}\right) \rho_{s} h}{\gamma_{2}}
\end{gathered}
$$

\section{Modeling the effect of testing, isolation and social protection of infected individuals}

Compartmental transmission models are commonly used in infectious disease epidemiology as a population-level modeling approach that subdivides the population into various classes based on the epidemiological status. Compartmental models are specified by a set parameters and ordinary differential equations that track the progression of the number of individuals within each class. Here, we developed an extension of the commonly used SEIR transmission model for modeling the transmission of COVID-19.

Individuals within the model are classified as susceptible $(\mathrm{S})$, latent $\left(\mathrm{E}_{1}\right)$, partially infectious but not yet symptomatic $\left(E_{2}\right)$, asymptomatic who are not tested $\left(A_{n}\right)$, asymptomatic who are tested $\left(A_{s}\right)$, infectious symptomatic who are not tested $\left(I_{n}\right)$, infectious symptomatic who are tested $\left(I_{s}\right)$, isolated infectious symptomatic $(\mathrm{J})$, isolated asymptomatic $\left(\mathrm{J}_{\mathrm{a}}\right)$, recovered $(R)$, and deceased (D). Constant population size is assumed, so $N$ is equal to the sum of individuals in all of the compartments. Further, seven classes can contribute to new infections: $E_{2}, A_{n}, A_{s}, I_{n}, I_{s}, J, J_{a}$. Susceptible individuals move to the latent $E_{1}$ class at a rate $\beta\left[q_{e} E_{2}(t)+q_{a} q A_{n}(t)+\right.$ $\left.q_{a} A_{s}(t)+q I_{n}(t)+q I_{s}(t)+h_{a} J_{a}(t)+h J(t)\right] / N$, where $\beta$ denotes the transmission rate. The transmission rate, $\beta$, was calibrated based on the baseline value of the basic reproductive number, $\mathrm{R}_{0}=2.4$ [1]. Parameter $q_{e}$ represents the relative transmissibility of exposed individuals in $\mathrm{E}_{2} ; q_{a}$ denotes the relative transmissibility of asymptomatic individuals; $q$ denotes the level of effectiveness of social protection such as wearing facemasks. $h$ represents the relative transmissibility of symptomatic individuals in isolation; $h_{a}$ denotes the relative transmissibility of asymptomatic individuals in isolation.

Individuals in $E_{1}$ progress to $E_{2}$ at rate $\kappa_{1}$. Individuals from $E_{2}$ are partially infectious, with relative transmissibility $\mathrm{q}_{\mathrm{e}}$, and progress at a rate $\kappa_{2}$, where a proportion $\rho_{\mathrm{a}}$ become asymptomatic and partially infectious (relative transmissibility $\mathrm{q}_{\mathrm{a}}$ ), and $1-\rho_{\mathrm{a}}$ become infectious. Among the proportion $\rho_{\mathrm{a}}$ who become asymptomatic, $\mathrm{n}_{\mathrm{s}}$ are tested, while $1-\mathrm{n}_{\mathrm{s}}$ are undetected. Further, among the proportion $1-\rho_{\mathrm{a}}$ that become fully infectious, $\rho_{\mathrm{s}}$ are tested, while $1-\rho_{\mathrm{s}}$ will be 
undetected. Asymptomatic individuals who are not tested and symptomatic individuals practice social protective behaviors such as wearing masks in public and increased handwashing, and thus have relative transmissibility q, which quantifies the effectiveness of those protective behaviors. Individuals within $A_{n}$ and $I_{n}$ classes (individuals who are not tested) recover at rate $\gamma_{1}$. Those who are tested $\left(I_{s}\right.$ and $\left.A_{s}\right)$ progress to the isolation class at diagnosis rate $\alpha$. Symptomatic individuals who are in isolation have a relative transmissibility $h$. Also, asymptomatic individuals in isolation have a relative transmissibility $h_{a}$. However, we assume perfection isolation for simplicity (i.e. $h=0$ and $h_{a}=0$ ). We also assume that asymptomatic individuals are not detected. Individuals who are isolated progress to the recovered class at a rate $\gamma_{2}$ or to the deceased class at a rate $\delta$.

Therefore, the system is defined by the following system of non-linear differential equations:

$$
\begin{gathered}
\dot{S}(t)=-\beta S\left[q_{e} E_{2}(t)+q_{a} q A_{n}(t)+q_{a} A_{s}(t)+q I_{n}(t)+q I_{s}(t)+h_{a} J_{a}(t)+h J(t)\right] / N \\
\dot{E}_{1}(t)=\beta S\left[q_{e} E_{2}(t)+q_{a} q A_{n}(t)+q_{a} A_{s}(t)+q I_{n}(t)+q I_{s}(t)+h_{a} J_{a}(t)+h J(t)\right] / N-\kappa_{1} E_{1}(t) \\
\dot{E}_{2}(t)=\kappa_{1} E_{1}(t)-\kappa_{2} E_{2}(t) \\
\dot{A}_{n}(t)=\kappa_{2} \rho_{a}\left(1-n_{s}\right) E_{2}(t)-\gamma_{1} A_{n}(t) \\
\dot{A}_{s}(t)=\kappa_{2} \rho_{a} n_{s} E_{2}(t)-\alpha A_{s}(t) \\
\dot{J}_{a}(t)=\alpha A_{s}(t)-\gamma_{2} J_{a}(t) \\
\dot{I}_{n}(t)=\kappa_{2}\left(1-\rho_{a}\right)\left(1-\rho_{s}\right) E_{2}(t)-\gamma_{1} I_{n}(t) \\
\dot{I}_{s}(t)=\kappa_{2}\left(1-\rho_{a}\right) \rho_{s} E_{2}(t)-\alpha I_{s}(t) \\
\dot{J}(t)=\alpha I_{s}(t)-\gamma_{2} J(t)-\delta J(t) \\
\dot{R}(t)=\gamma_{1}\left(A_{n}(t)+I_{n}(t)\right)+\gamma_{2}\left(J(t)+J_{a}(t)\right) \\
\dot{D}(t)=\delta J(t)
\end{gathered}
$$

\section{Schematic of the model diagram}

The population is classified into 11 epidemiological states: susceptible $(\mathrm{S})$, latent $\left(\mathrm{E}_{1}\right)$, partially infectious but not yet symptomatic $\left(\mathrm{E}_{2}\right)$, asymptomatic who are not tested $\left(\mathrm{A}_{\mathrm{n}}\right)$, asymptomatic who are tested $\left(A_{s}\right)$, infectious symptomatic who are not tested $\left(I_{n}\right)$, infectious symptomatic who are tested $\left(\mathrm{I}_{\mathrm{s}}\right)$, isolated infectious symptomatic $(\mathrm{J})$, isolated asymptomatic $\left(\mathrm{J}_{\mathrm{a}}\right)$, recovered $(\mathrm{R})$, and deceased (D). Model parameters are described in Table 1. 


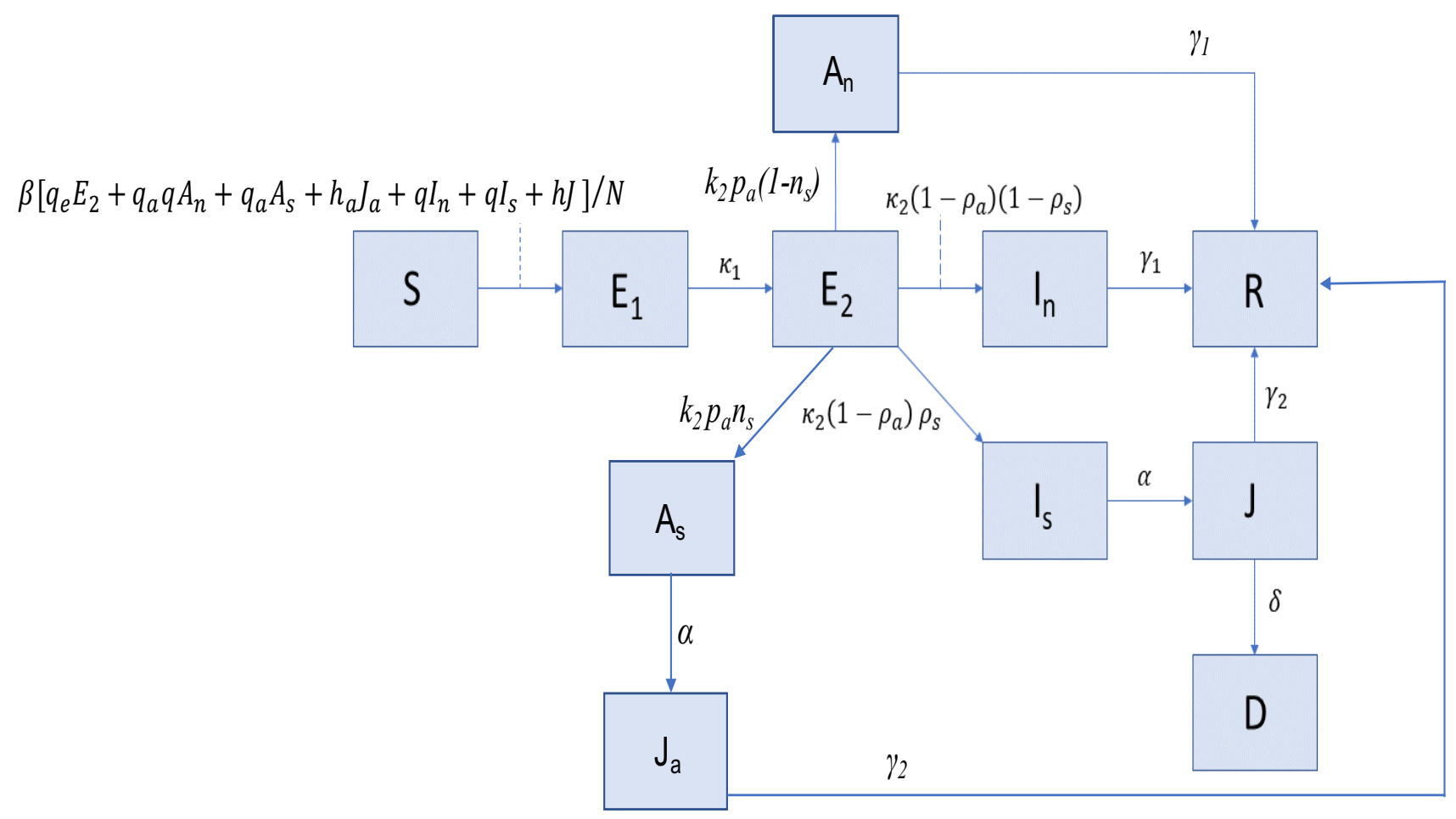

Table 1. Parameter descriptions and values for model

\begin{tabular}{|c|l|c|c|}
\hline Parameter & Description & Calibrated for $\mathrm{R}_{0}=2.4$ & References \\
\hline$\beta$ & Transmission rate & $0-1$ & Assumed here \\
\hline$h$ & $\begin{array}{l}\text { Relative transmissibility of } \\
\text { symptomatic individuals in } \\
\text { isolation }\end{array}$ & $0-1$ & Assumed here \\
\hline$h_{a}$ & $\begin{array}{l}\text { Relative transmissibility of } \\
\text { asymptomatic individuals in } \\
\text { isolation }\end{array}$ & 0.1 & {$[2]$} \\
\hline$q_{e}$ & $\begin{array}{l}\text { Relative transmissibility of exposed } \\
\text { individuals in E }\end{array}$ & 0.4 & {$[2]$} \\
\hline$q_{a}$ & $\begin{array}{l}\text { Relative transmissibility of } \\
\text { asymptomatic individuals }\end{array}$ & & \\
\hline
\end{tabular}


medRxiv preprint doi: https://doi.org/10.1101/2020.04.01.20049981; this version posted May 6, 2020. The copyright holder for this preprint (which was not certified by peer review) is the author/funder, who has granted medRxiv a license to display the preprint in perpetuity.

All rights reserved. No reuse allowed without permission.

\begin{tabular}{|c|c|c|c|}
\hline$q$ & $\begin{array}{l}\text { Level of effectiveness of personal } \\
\text { protective behavior }\end{array}$ & $0-1$ & \\
\hline $1 / \kappa_{1}$ & Mean latency period in $\mathrm{E}_{1}$ & 2.5 days & {$[3-7]$} \\
\hline $1 / \kappa_{2}$ & Mean latency period in $\mathrm{E}_{2}$ & 2.5 days & {$[5-8]$} \\
\hline$\rho_{a}$ & $\begin{array}{l}\text { Proportion of asymptomatic } \\
\text { infections }\end{array}$ & $0.2,0.4$, and 0.6 & {$[9,10]$} \\
\hline$n_{s}$ & $\begin{array}{l}\text { Proportion of asymptomatic } \\
\text { individuals who are tested }\end{array}$ & $0-1$ & Assumed here \\
\hline$\rho_{s}$ & $\begin{array}{l}\text { Proportion of symptomatic } \\
\text { infectious individuals that undergo } \\
\text { testing }\end{array}$ & $0-1$ & \\
\hline $1 / \alpha$ & $\begin{array}{l}\text { Time from detection to } \\
\text { confirmation and isolation }\end{array}$ & 1-2 days, and 12 hours & \\
\hline $1 / \gamma_{1}$ & $\begin{array}{l}\text { Recovery rate for individuals in } A_{n} \\
\text { or } I_{n}\end{array}$ & 7 days & {$[3,4]$} \\
\hline $1 / \gamma_{2}$ & $\begin{array}{l}\text { Average time from confirmation to } \\
\text { recovery }\end{array}$ & 5 days & {$[11]$} \\
\hline$\delta$ & $\begin{array}{l}\text { Disease-induced death rate among } \\
\text { confirmed symptomatic individuals }\end{array}$ & $\delta=0.04$ & {$[12]$} \\
\hline
\end{tabular}

**Indicates the value was estimated

Figure 1. Thresholds for social protection and testing / isolation needed to bring $\mathrm{R}<1$.

Results: $20 \%$ asymptomatic with 12 hour testing turnaround

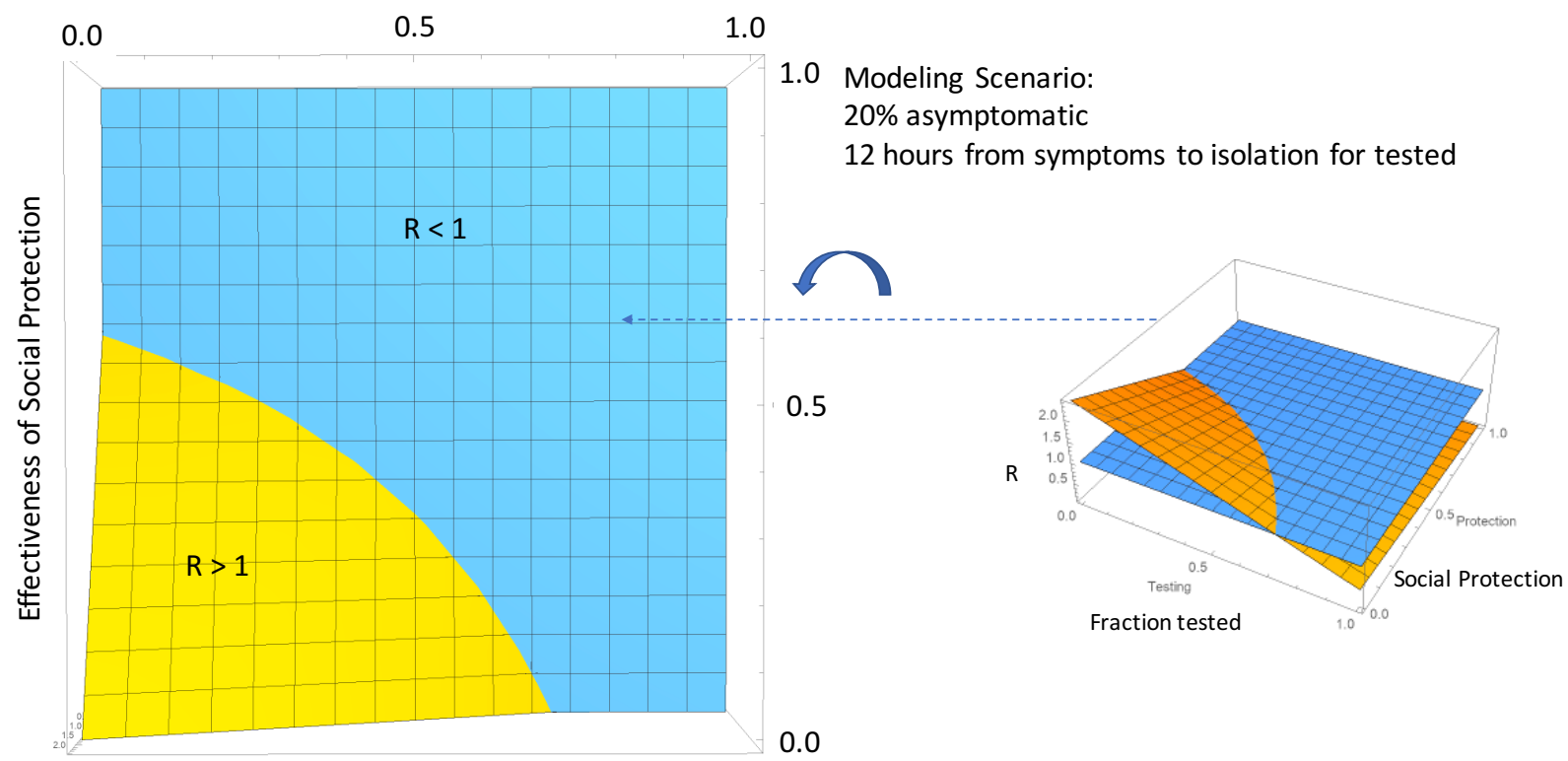

Fraction tested and isolated 
medRxiv preprint doi: https://doi.org/10.1101/2020.04.01.20049981; this version posted May 6, 2020. The copyright holder for this preprint (which was not certified by peer review) is the author/funder, who has granted medRxiv a license to display the preprint in perpetuity.

All rights reserved. No reuse allowed without permission.

Results: $\mathbf{4 0 \%}$ asymptomatic with next day testing turnaround

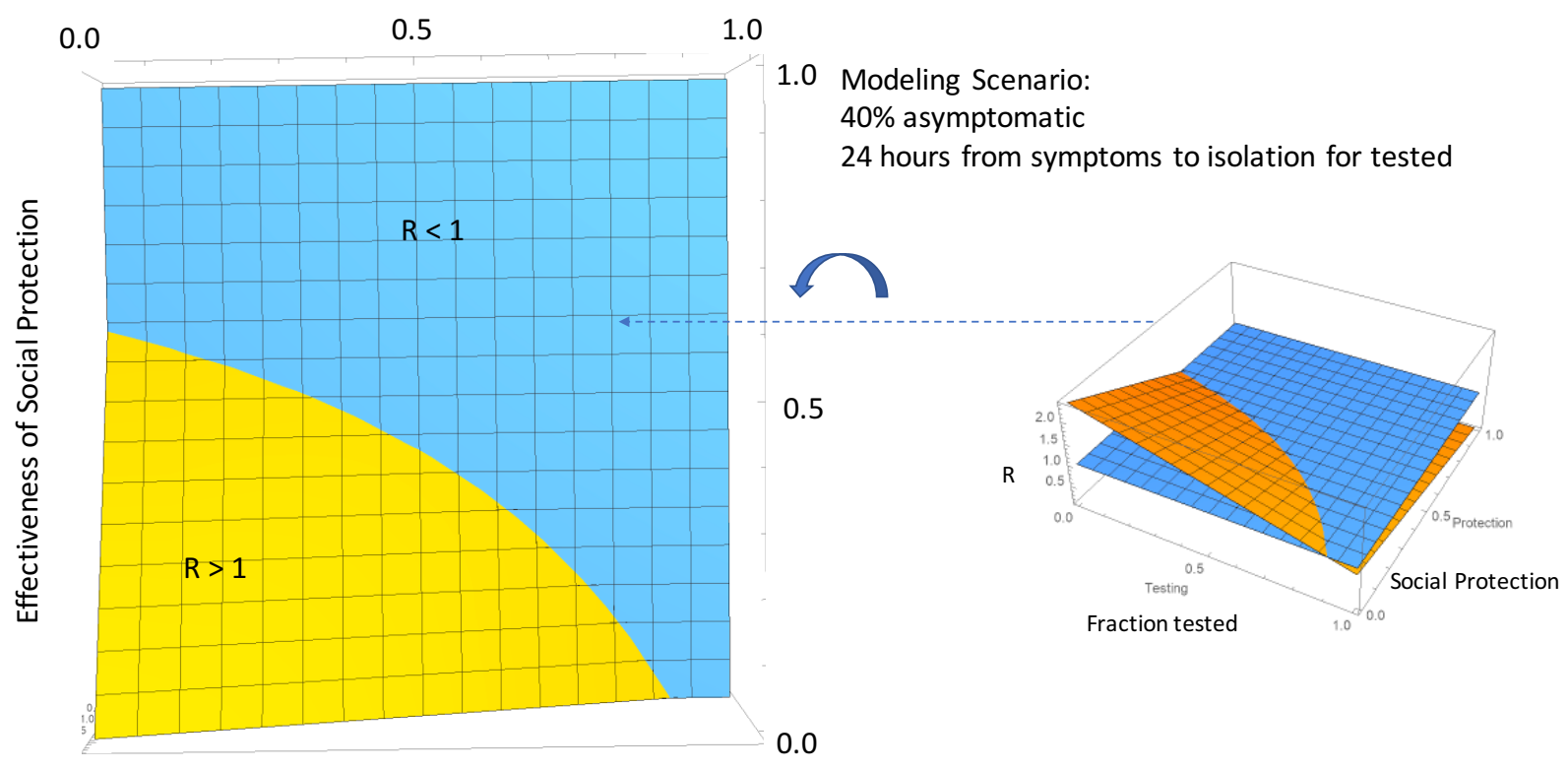

Fraction tested and isolated

Results: $60 \%$ asymptomatic with two-day testing turnaround

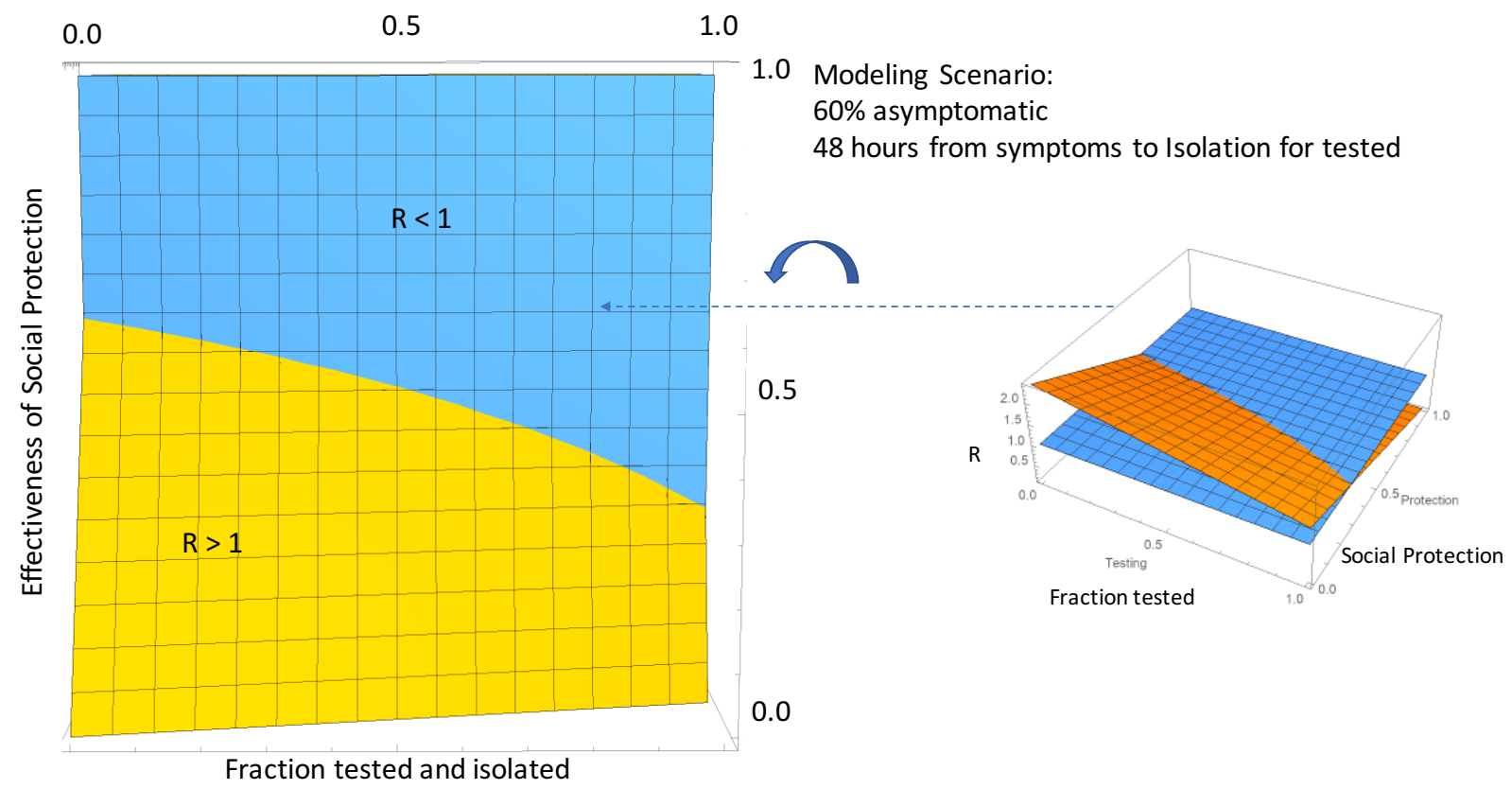


medRxiv preprint doi: https://doi.org/10.1101/2020.04.01.20049981; this version posted May 6, 2020. The copyright holder for this preprint (which was not certified by peer review) is the author/funder, who has granted medRxiv a license to display the preprint in perpetuity.

All rights reserved. No reuse allowed without permission.

\section{References}

1. Li Q et al. Early Transmission Dynamics in Wuhan, China, of Novel CoronavirusInfected Pneumonia. N Engl. J. Med. 2020.

2. Chowell, G., et al., SARS outbreaks in Ontario, Hong Kong and Singapore: the role of diagnosis and isolation as a control mechanism. Journal of Theoretical Biology, 2003. 224(1): p. 1-8.

3. Peng, L., et al., Epidemic analysis of COVID-19 in China by dynamical modeling. 2020: doi: https://doi.org/10.1101/2020.02.16.20023465

4. Zhou, C., Evaluating new evidence in the early dynamics of the novel coronavirus COVID-19 outbreak in Wuhan, China with real time domestic traffic and potential asymptomatic transmissions. 2020: doi: https://doi.org/10.1101/2020.02.15.20023440

5. Linton, N., et al., Incubation Period and Other Epidemiological Characteristics of 2019 Novel Coronavirus Infections with Right Truncation: A Statistical Analysis of Publicly Available Case Data. 2020: doi: https://doi.org/10.1101/2020.01.26.20018754.

6. Sun, H., et al., Tracking and Predicting COVID-19 Epidemic in China Mainland. 2020: doi: https://doi.org/10.1101/2020.02.17.20024257

7. Zou, L., et al., SARS-CoV-2 Viral Load in Upper Respiratory Specimens of Infected Patients. New England Journal of Medicine, 2020.

8. You, C., et al., Estimation of the Time-Varying Reproduction Number of COVID-19 Outbreak in China. 2020: doi: https://doi.org/10.1101/2020.02.08.20021253

8. Nishiura, H., et al., Estimation of the asymptomatic ratio of novel coronavirus infections (COVID-19). medRxiv, 2020: p. 2020.02.03.20020248.

10. Mizumoto, K., et al., Estimating the Asymptomatic Proportion of 2019 Novel Coronavirus onboard the Princess Cruises Ship, 2020. 2020: doi:

https://doi.org/10.1101/2020.02.20.20025866.

11. China CDC, The Epidemiological Characteristics of an Outbreak of 2019 Novel Coronavirus Diseases (COVID-19) - China, 2020, T.N.C.P.E.R.E. Team, Editor. 2020: China CDC Weekly.

12. Chinese National Health Commission. Reported Cases of 2019-nCoV. 02/02/2020 03/06/2020]; Available from:

https://ncov.dxy.cn/ncovh5/view/pneumonia?from=groupmessage\&isappinstalled=0. 